Terbit online pada laman web jurnal : http://e-journal.sastra-unes.com/index.php/JILP

\begin{tabular}{|c|c|c|}
\hline \multirow[b]{2}{*}{$\begin{array}{l}\text { Fakultas Sastra } \\
\text { Universitas Ekasakti }\end{array}$} & \multicolumn{2}{|c|}{$\begin{array}{c}\text { (JURNAL ILMIAH LANGUE ANJ PAROLE) } \\
\text { VOLUME } 3 \text { NOMOR } 2\end{array}$} \\
\hline & $\begin{array}{c}\text { ISSN : 2581-0804 } \\
(\text { Media Cetak }) \\
\end{array}$ & $\begin{array}{c}\text { E-ISSN : 2581-1819 } \\
\text { (Media Online) } \\
\end{array}$ \\
\hline Received: 28-07-2020 & Revised: $14-08-2020$ & Available online: $31-08-2020$ \\
\hline
\end{tabular}

\title{
DEVOTION AND COMMITMENT IN A CONTRADICTORY CONDITIONSAS SEEN IN THE NOTEBOOK BY NICHOLAS SPARK
}

\author{
Helmita, Elsa Mayora Putri \\ Fakultas Sastra Universitas Ekasakti \\ elsamayoraputri97@gmail.com
}

\begin{abstract}
The problem in this thesis is Devotion and commitment in a contradictory conditions in the relationship between Noah and Allie who have differences in social status. Until their relationship was opposed by Allie's mother, even so Allie remained devotion to choose Noahh. Devotion and commitment to the contradictory conditions between Noah and Allie also occur when they are old. Noah remained loyal to Allie when she suffered from Alzheimer's disease.

The object of this study was The Notebook novel by Nicholas Sparks. This research uses Sigmund Freud's theory of personality psychology. The results of this study are the figures Noah and Alli have personality aspects that refer to Sigmund Freud's theory of id, ego, superego. The writer uses descriptive analysis method and qualitative method. The author carries out a systematic procedure with an understanding of the novel, figures Noah and Allie, and also structural theory.

This study aims : (1) to analyze the importance of loyalty and commitment in contradictory conditions. (2) to describe the loyalty and commitment contained in the Novel The notebook. (3) to explain the loyalty and commitment shown by Noah and Allie after marriage.

Based on the results of this analysis it can be concluded that the problem faced by the main character is his deep love and loyalty to his wife, Noah did everything for Allie, including writing to him for two years even though his letter was never responded by Allie. But when they met for the first time after being separated for quite a long time their love for each other was still there. Until they married and aged together and Allie contracted Alzheimer's disease, but Noah remained faithful with her.
\end{abstract}

Keywords: Devotion, Psychology of Literature, Personality, Sigmund Freud, Novel

(C) 2020Jurnal JILP

\section{INTRODUCTION}

The background of the problems provides the reasons for the problem in this analysis. Therefore, the writer begins with describing the fact, problem, and solution to this writing. The fact in this analysis is the love story from two people that have the same feelings, and they should live happily ever after. However, the problem comes when the fate decides the other story, a story about devotion and commitment in a relationship that is opposed because it has a diffrent social status and when devotion is tested when their partners have Alzheimer's disease. The solution to this problem is in a relationship there must be devotion and commitment even though there are many contradictions in the relationship.

\section{https://doi.org/10.36057/jilp.v3i2.404}

Jurnal JILP (Jurnal Ilmiah Langue and Parole) Vol. 3 No. 2 (2020) ISSN : 2581-0804

This work is licensed under a Creative Commons Attribution-NonCommercial 4.0 International License. 
First, the writer gives reasons to choose the problem of devotion and commitment in a contradictory conditions. In the love story between Noah and Allie their relationship was opposed by parents. During that time, Noah sent a letter 365 times to Allie and never got a reply. They continued their lives. Noah and his friends were conscripted in North Africa and Europe. Try as busy as possible to be able to embed his first love. While Allie became a nurse for war victims. Until one day Allie fell in love with a war soldier who was once named Lon. Ideal young man who is established and has the same social status as Allie. Moreover, for Anne, Allie's mother who had broken the relationship between Allie and Noah because Niah was not a rich man and had the same social status as Allie's family. Until finally they were news in a local newspaper that contained Noah's profile with his old house. although Allie was confused about choosing Noah or Lon, she finally chose Noah and married him.

There is devotion and commitment in a contradictory conditions in the relationship between Noah and Allie. When Noah remained faithful to Allie even though they had not been in touch for seven years because of their relationship which was not condoned by Allie's mother. However, the letter Noah wrote and sent to Allie for two years never received a reply from Allie's mother who kept all the letters Noah sent to Allie and the same Allie did not know about that. Differences in social status between them make their relationship must stop. Allie did the same thing that Noah did was Allie and wrote a letter to Noah but he never sent it to Noah because he was afraid of the fact that Noah could see it.

Allie never got a letter from Noah so Allie thought that only she still remembered about Noah, even though receiving Noah had sent 356 letters to Allie which meant that Noah had not been able to choose Allie either. The last time they got the chance to meet again after seven years of separation, when Noah's profile finally had enough money after working with Mr. Goldman and decided to return to his hometown and buy the house that Allie had occupied and saved first. Noah hopes that with this house he will be able to bring Allie back to him. When Allie learned about the news because she saw Noah's profile collected in the local newspaper,
Allie finally decided to access Noah again. Allie will get married in three weeks with her fiancée who is well established and has the same social status as her. When they were talking about the future it was finally revealed that Noah had sent 356 letters to Allie and never received a reply. Noah thinks because Allie has never replied to his letter because Allie doesn't want to have contact with Noah anymore. Allie took and kept all the letters sent to Allie without Allie's knowledge.

When Allie began to ask what she was looking for in the world. Does she have to choose to live with someone who chooses to be comfortable or should choose to live with someone who has the same social status as her. Only Noah made Allie comfortable, but Allie's mother really expected Allie to marry someone who had the same social status as hers. After Allie wrote the letters that Noah had sent after Allie's mother finally gave them to her, Allie was one hundred percent aware of what to choose after reading the letters over and over. Finally Allie chose Noah, the person who chose comfortably.

After the wedding Allie and Noah were blessed with five children. Noah and Alli's devotion in contradictory conditions also existed when they were married. Of their five children, they have to lose one child which makes them very sad. Parents will be very sad when they lose their child. When Allie and Noah were very old and their children had become adults when it was considered Allie was declared to have Alzheimer's disease. Noah stays faithful and is always by Allie's compilation, even Allie can't remember anyone. Noah and Allie live in nursing homes, Allie completely forgets about everything, forgets their stories.

Noah faithfully kept weakening Allie, rereading their diaries. Reading it to Allie expects Allie to remember who is being told by Noah. The story of their story and hopes that it can make Allie remember it before just taking andforgetting again and thinks Noah is only for strangers. Until finally Noah remained faithful and perfect on Allie's side even in conflicting conditions and they finally arrived at the nursing home. The sample of data from devotion and commitment in contradictory condition can be seen from the statement of Noah, He loves Allie 
even when she have Alzheimer's disease and can't remember anything:

"I love you. I am who I am because of you. You are every reason, every hope, and every dream I've ever had, and no matter what happens to us in the future, we are together the greatest day of my life. I will always be yours. " (126).

Second, the background is focused on the reason for choosing the novel, itcan be seen from the ability of novel to describe the narrations and the dialogues in detail in order to give the clear understanding about the literary work's environment and the depth of characters' thought and feeling. The novel has been a part of human culture for over a thousand years, the novel has risen to prominence and remained one of the most popular and treasured examples of human culture and writing. A novel is a fictional piece of prose usually written in a narrative style. Novels tell stories, which are typically defined as a series of events described in a sequence. The word novelthat was not even used until the end of the $18^{\text {th }}$ century is an English transliteration of the Italian word novella, used to describe a short, compact, broadly realistic tale popular during the medieval period. It deals with a human character, man as a social being. There have been stories and tales for thousands of years, but novels must combine a few unique characteristics in order to be defined as such. According to Bernet and Burton (1991), novel can be defined as:

First, a novel is

written down, rather

than told through an

oral account. Secondly,

novels are meant to be

fictional in form,

differentiating them

from myths, which are

said to have their basis

in reality.

This novel is often beloved for their creation of spectacular worlds, empathetic characters, and carefully thought-out arguments. They are often seen as a boundless realm of exploration and creativity, with subgenres springing up to include nearly every type of subject that can be written about. The literary style remains cost-effective despite the range of imaginary things that can be put into novels, unlike the soaring costs of special effects and computer graphics needed to make a fantastical movie, a novel requires only imagination and talent to create massive worlds and detailed characters.

Third, the reason to choose the author, Nicholas Sparks. This novel is a romantic novel released in October 1996.18 novels by Nicholas spark have been published and become bestselling novels in the United States and around the world. a novelist and screenwriter from the United States. To date, Most of the novels are themed about love, fate, and romance. Eleven of his novels have been adapted to the big screen, including Message in a Bottle, A Walk to Remember, The Notebook, Nights in Rodanthe, Dear John, The Last Song, The Lucky One, Safe Haven, The Best of Me, The Longest Ride, and The Choice and the notebook is the first novel work. Fourth, the reason for choosing a novel, in this case the notebook from Nicholas sparks, is because of the love story between Noah and Allie who have devotion and commitment in contradictory conditions in their relationship. Despite the differences in social status until Allie suffered Alzheimer's disease, Allie and Noah continued to have devotion to each other even when uncontradictory condition.

The title of The Notebook seems to be of the opinion that the diary book will really help Allie try to make up her story with Noah. Their struggle to get back together even though their relationship was opposed by Allie's mother was due to differences in social status between the two of them. The Notebook's title is like Allie's diary that Noah will read to repeatedly over and over until finally Allie can remember who she is and Noah recall their story even though only temporarily caused by Allie's illness, Alzheimer's. 


\section{RESEARCH METHODS}

The data collecting procedures is focused in the process of the writer collect the data by reading the novel and noted the statements that related to the problem. In the collecting data the writer applies library research. It means that the writer applies the data which the writer takes from library. Pradopo in Metodologi Penelitian Sastra (2001:153) states:

Penelitian $r$ pustaka
adalah observasi yang
dilakukan dalam pustaka,
dimana penulis mendapatkan
data dan informasi tentang
objek penelitian melalui buku
dan media audiovisual yang
berhubungan dengan topic.

The library research is the observation that is executed in the library, which the writer gains the data and information about his object through the books and other audiovisual equipment that related and relevant to the topic.

Through this library research activity, the writer gains some information to understand the problem. In order to gain more information, the writer also executes the internet research as to support the data from library research, the data is received in files form.

In concern with library research, the writer takes the novel The Notebook by Nicholas Spark as main data of this research. The writer also collects books as references of this writing and theories to solve the research problems that conveys in this research.

\section{Method of Analyzing the Data}

In analyzing the data, the information from data collection is processed and presented in form of thesis. In the application, the writer uses structural method. According to Pradopo (2001:69). The researcher has role to explain literary work as a structure based on the elements that build them. From this quotation, structural method has functions to explain the intrinsic elements of literary work.

The procedure starts by reading the main source of analysis, which is the novel The Notebook. After understanding the story, the procedure moves to find the intrinsic elements in the novel, which are plot, theme, characters, setting of place, setting of time, and point of view. Next, the information received from data collection procedure is studied by limiting on the analysis of the intrinsic element, there is no extrinsic element such as psychology or sociology in the analysis. After the data are organized, the writing is composed based on standard of thesis writing.

\section{Technique of Collecting the Data".}

According to Djaman Satori and Aan Komariah (2011: 103) the definition technique of collecting the data is as follows: "Collecting data in scientific research is a procedure systematic to receive the data needed. " From the above understanding it can be seen that the technique Welcoming very difficult data with the research problem you want solved. Recording techniques according to Bogdan and Biklen (in Moleong, 2009: 209) are written records of what is heard, seen, experienced, and thought about in the context of data collection and reflection on data in qualitative research.

According to Junice Mc Durcy (in Moleong, 1999: 248), recording techniques with qualitative analysis are carried out to obtain a good level of accuracy. According to Sugiyono (2005: 224) the technique of data collection is the most strategic step in research, because the main purpose of the research is to obtain data.

In addition, the authors use the literature study method. Siswantoro (2010: 76). This method is a way to collect data by studying various literature as a reference in writing reports. The act of reducing data is nothing but selecting data by focusing on data that is the object of study. As for the data in this study are excerpts the Notebook novel by Nicholas Spark that illustrate the 
psychological aspects related to the psychological about Devotion and commitment in a contradictory condition.

\section{Technique of Analyzing the Data}

The data analyzing procedures concern with the ways of the writer to conduct the analysis of the data. In this research the writer applies structural technique. It looks the internal factor of literature that covers the internal element of literary work such the actions of the main characters.

From the explanation above, structural technique has two functions which explain the internal factor of literature. The primary data is taken from novel itself, the writer tries to analyze it by using the information in form of quotations based on the novel itself. In doing this research, the writer starts by analyzing some intrisic elements of this novel, after that tries to find extrinsic element which becomes the basic of the problem that will be analyzed.Further, Abrams and Harpham (2009:22), the definition of character is:

$\quad$ The person
presented in
dramatic or
narrative work, who
are interpreted by
the reader as being
endowed with moral,
dispositional, and
emotional qualities
that are expressive
in what they say, the
dialogue, and what
they do in the action.

To find out the psychological values of a character and find out what devotion and commitment in a relationship are illustrated by Nicholas Spark's The Notebook novel, the data obtained is then processed using a qualitative descriptive method, which is a method that describes the results of the analysis in accordance with data found, then arrange it carefully and in detail (Arikunto, 2006: 12). The technique of analyzing data from the novel The Notebook is then the author arranges in the form of reports, including Descriptive Analysis. In this study, the authors used descriptive analysis that was qualitative in nature. Qualitative descriptive analysis in this study was used to describe the psychological aspects of devotion and commitment in relationships based on the novel The Notebook. Qualitative descriptive analysis, according to Arikunto (2006: 12), is a method that describes the results of the analysis in accordance with the data found, then arranges them carefully and in detail.

Qualitative descriptive research is one of the types of research included in this type of qualitative research. The purpose of this study is to reveal events or facts, circumstances, phenomena, variables and circumstances that occur when the study takes place by presenting what actually happened. This study interprets and describes the data concerned with the current situation, attitudes and views that occur in a society, the conflict between two or more circumstances, the relationship between variables that arise, differences between existing facts and their influence on a condition, etc.

According to Nazir (1988), descriptive method is a method of examining the status of a group of humans, an object, a set of conditions, a system of thought or a class of events in the present. The purpose of this descriptive study is to make a description, description, or painting systematically, factually and accurately of the facts, the characteristics and the relationship between phenomena investigated. While according to Sugiyono (2005) states that descriptive method is a method used to describe or analyze a research result but not used to make broader conclusions. According to Whitney (1960), descriptive method is the search for facts with the right interpretation.

The problems that can be investigated and investigated by qualitative descriptive research refer to quantitative studies, comparative studies (comparisons), and can also be a correlational study (relationship) between one element and other elements. This research activity includes collecting data, analyzing data, interpreting data, and finally formulating a conclusion that refers to the analysis of the data. 


\section{RESULTS AND DISCUSSION}

The focus in this sub-analysis is the character of Noah Calhoun, because of his devotion to his first love Allie Nelson. The story begins in a nursing home, an old man reads a story from his notebook to another old woman. It tells the story of a young man named Noah Calhoun, who falls in love with a girl named Allie Nelson. The flashback story to 49 years ago where a 31-year-old young man named Noah Calhoun managed to buy the old house of his dreams and renovate it as before. This made local newspapers raise Noah's profile and his old home. Noah had promised to turn the old house into Allie's dream house. A large white house, with a large veranda to drink tea and enjoy tea and of course a special room for painting because Allie loves to paint. The dream house was realized by Noah, although it was renovated with a half temper. Noah had seen Allie with Lon at the restaurant. With a broken heart, Noah still believes that Allie will return to him. That house will make Allie to him. While not so far a woman named Allie Nelson saw the news about Noah, she then decided to go and to see the house firsthand and of course to meet with Noah.

Noah Calhoun, an ordinary man who likes to read poetry. In the summer of 1946, he fell in love and it was his first love when Noah was 17 years old and Allie was 15 years old. Noah and Allie spent time together during the summer until Allie had to return to the city, and their relationship which could only be a memory. Ms. Allie did not approve of Noah and Allie's relationship because of differences in social status between the two of them. For seven years they separated and for two years Noah always sent a letter to Allie hoping he would get a reply and get in touch with Allie again.

\footnotetext{
"You and I were different. We came from different worlds, and yet you were the one how taught me the value of love. You showed me what it was like to care for another, and I am a better man because of it. I don't
}

want you to ever forget that." (57).

The unrequited letters from Allie, the second world war was over, years passed, and had tried to have relationships with many women but still Noah was unable to forget Allie. As Noah's friend had said to him, that Noah was unable to forget Allie.

"you know, the
ghost, the memory. I
bee watching you
wroking day and night,
slavin so hard you
barely have time to
catch your breath.
People do that for three
reasons. Either the
crazy, or stupid, or
trying to forget. And
with you, I knew you
was trying to
forget"(8).

For reasons of forgetting his relationship with Allie, Noah decided to leave New Bern. He first went to Norfolk and worked at the shipyard for six months, then moved to New Jersey. He finally found work at a disposal site for $\mathrm{Mr}$ Goldman's used goods. Noah worked for Goldman for a long time, so much so that Noah was promoted. He is a business intermediary, and oversees thirty staff. For years also Noah could not forget his first love.

At the age of twenty-six, a war broke out and Noah intended to join him to register for war. When he said goodbye to Goldman, he was given assets for his company. For three years, Noah was a soldier exploring Africa and the forests of Europe because his unit was almost always involved in warfare. After the war ended, he got a letter from a lawyer representing Goldman. He was told that Goldman had died and Noah was making a lot of money from the business he owned. Noah returned to New Bern to buy a new home for him and his father. The house is the residence that Allie's family lived in before they moved. Shortly after his father died. 
Noah Calhoun managed to buy the old house of his dreams and renovate it as before. This made local newspapers raise Noah's profile and his old home. Noah had promised to turn the old house into Allie's dream house. A large white house, with a large veranda for tea and tea and of course a special room for painting because Allie loves to paint. The dream house was realized by Noah, although it was renovated with a half temper. Noah had seen Allie with Lon at the restaurant. With a broken heart, Noah still believes that Allie will return to him. That house will make Allie to him. While not so far a woman named Allie Nelson saw the news about Noah, she then decided to go and to see the house firsthand and of course to meet the love of her youth Noah.

Until finally Allie came back in front of Noah. Allie's arrival, of course surprised Noah, they then told the past where they first met. Noah is happy with Allie's arrival and wants their relationship to go back to the way it used to be. Even so, Noah never forced Allie, he handed all the decisions to Allie even though he actually wanted to get back with Allie. Noah still can't forget Allie and their memories.

\begin{abstract}
" I guees I still
look for the kind of

love we had that summer," Noah thought about what she had said, thought about the relationship he'd had since he'd last seen her. "how about you?" she asked. "did you ever think about us?", "All the time, I still do." he said, "Are you seeing anyone?", "No," he ananswere, shaking his head (37).
\end{abstract}

On the other hand, actually Allie will be heading to her wedding in a matter of days. Allie is engaged to Lon, a strong and established lawyer. Their marriage is on the verge of being in the eye. However, there is something that makes Allie remember Noah, that is, Noah's face adorns Noah's picture, reporting that the man has renovated their house in New Bern. Allie decided that everything had to be resolved, she had to meet Noah. On the grounds of wanting to take a break from wedding preparations, Allie went to New Bern. And that's where he met Noah again.

When the meeting happened again, the seeds of love between the two were apparently not extinguished. Noah and Allie actually resumed their illicit relationship. Anna Nelson apparently realized something was not right on Allie's trip back to New Bern. He went to Noah's house and found his son there. Immediately it was revealed that all this time, her mother had hidden Noah's letter so that it did not reach Allie's hands. His mother also warned that Lon was suspicious of Allie and had followed her to this place. His mother asked his son to return home. However, one message from his mother to Allie was that Allie follow her heart in making decisions. It's not that Allie's parents didn't like Noah, but because Noah didn't come from among them because they were too poor, they would never agree with their relationship.

"I know you
don't think so, but I
always liked you. I just
didn't think you were
right for my daughter.
Can you understand
that?" He shook his
head as he answered.
"No, not really. It
wasn't fair to me, ant it
wasn't fair to Allie.
Otherwise she wouldn't
here (74).

Noah was very happy with Allie's arrival, recalling the love story of her youth. Even though Noah really hoped that Allie would come back to him, he never forced Allie. All decisions are left to Allie. Even though Allie didn't choose him, he will remain loyal to remember the happy days he had with Allie. Allie, who was confused about choosing to remain in comfort with Noah or had to continue to choose her fiancée who was well established and had the same social status as her, in the end Allie still chose to follow her heart.

"I know what you're trying say, Ican see it in your eyes. But 
I dont want to understand it, Allie. I don't want it to end this way. I don't want it to end at all. But if you leave, we both know we'll never see aech other again." She leaned into him and began to cry harder as Noah fought back his own tears. He wrapped his arms around her. "Allie, i can't force you to stay with me. But no matter what happens in my life, I'll never forget these last couple of days with you. I'v been dreaming about this for years" (73).

The story goes back to old Noah who was none other than the old grandfather who was in the nursing home earlier, surprisingly it turned out to be his diary and he was reading his diary in the hope that Allie could recall himself and their past, because Allie was currently suffering alzeimer. Noah will faithfully read the diary to Allie until Allie can recall even just for a short time, although it is very sad for Noah to see Allie who feels guilty for not being able to remember everything, but Noah is still very happy that she can spend time with Allie while reminiscing about their past through her notebook.

\section{Allie's devotion to Noah was in a contradictory conditions because her relationship was opposed by Allie's mother.}

In this part, the analysis is focused on the character of Allie Nelson. Allie, 29, is now engaged to another man, but she realizes that her love for Noah has never faded in time. His first love at a young age that was hard for him to forget, but their world was so different. Facing her marriage that was only a few weeks away, Allie was forced to question what her hopes and dreams were for the future, and with whom she wanted to live the future.

They were first met each when they were fifteen and seventeen years old. During summer vacation, Allie and Noah meet at the festival and spend summer vacation time together. The feeling of love has appeared. Even when they have to be separated by time for years, the taste doesn't fade. There is no reason for Allie not to go to the city with her mother and their relationship is prohibited by Allie because of the existence of a social status difference between them.

Until Allie never knew whether Noah still remembered it or not because Allie never received a single letter from Noah because it was not known to Allie, apparently all the letters sent to Allie never reached Allie because Allie's mother kept all the letters Noah sent to Allie. For seven years there was no news but Allie still could not forget Noah. Allie volunteered at a hospital that treated war victims. It was there that he met Lon Hammond Jr. (James Marsden). Lon became the perfect man. Not only in Allie's eyes, but also her family. Rich, handsome, smart and had rank in the military, Lon had a complete package of perfection to be a son-in-law.

Once Lon applied and gave her a beautiful ring, Allie immediately said "I do". But when he said that, he looked at Lon's face. Allie's heart hesitated. And the more doubt when looking at the newspaper, there was a picture of Noah displayed in front of a large white house, with advertisements to be sold.

Before getting married, Allie had an unexpected opportunity to return to meet Noah. The answers are only two, she chose to meet the past or walk forward with her future husband. Finally he chose to meet again with his past, Noah.

The meeting revived that feeling again. Becoming stronger, harder to leave, then Allie hesitated herself to choose to leave Noah again and reap her dream to be able to settle down with her wealthy and respected future husband, or even re-knit their delayed love story. Through a diary, they both remember their love story. Because with a diary, every moment and memory will remain stored. So, one of them rewrote the story in a diary to remain immortal, at least for both of them. Even though Allie still has feelings for Noah, she really doubts what she should choose. On the other hand he was engaged and only a few days he would get married. Actually Allie has feelings for Noah and her fiance named Lon. Allie loves them both, but in a different way. 


\begin{abstract}
"do you love
him?" "Yes, I do."

Allie answered softly,

"verry much."Do you

love Lon?" "Yes, I do.

I love him too. Dearly,

but in diffrent way. He

doesn't make me feel

the way Noah does

(76).
\end{abstract}

During their separation and no news from each other, and the letter Noah sent to Allie, unfortunately, none of the letters was received by Allie. Through this meeting Allie realized that Noah did not just leave, he left because of the pressure of his mother and the letter that survived two years Noah sent him never reached him, unfortunately the letters that came were all taken by Allie's mother without being given to Allie. Actually, not only Noah wrote a letter to Allie, but Allie also wrote a letter to Noah but he never sent it. Allie was doubtful and afraid that Noah did not have the same feelings as she did, and Allie was afraid that Noah had forgotten her.

"It wasn't just up
to you, Noah. I didn't
tell you, but I wrote
you a dozen letters
after I go home. I just
never sent them." She
said, "Why?" Noah
was surprised. "I guees
I was too afraid." "Of
what?" "That maye it
wasn't as real sa I
thought it was. That
maybe you forgot me
(68).

The choice is in Allie's hands. Noah could not force but hoped that Allie would hear his heart that he could not forget her. Even though Alli loves Noah more than his fiancé but he doesn't want to hurt the fiance's heart. Allie has different feelings for Noah, and is confused about having to choose between comfort or choosing Lon who is established and has the same social status as him. He could not lie to his heart if he preferred Noah over Lon and Noah kept leaving all decisions to Allie and convinced
Allie that Noah actually knew that Allie loved Noah more than Lon.

"I don't know, I
really don't know.
When I was in the
living room, I kept
asking myself what I
really wanted in my
life." She squeezed his
hand. "And do you
know what the answer
was? The answer was
that I want you. I want
us. I love you and I
always have." She took
breath before going on.
"But I also want a
happy ending without
hurting anyone." "You
can't live your life for
other people. You've
got to do what's right
for you, even if it hurts
some people you love."
he said (78).

Until finally Allie decided to go and return to Lon because Allie felt that if he chose Noah it would not be fair to Lon. Allie will hurt her fiancé if she chooses Noah. When Allie was in the car, she decided to read the letter her mother gave to Allie. The letter he should have read first. Allie stopped her car and read the letter there and found the date in March 1935. Allie read the letter over and over until she decided to follow her heart to choose Noah.

"My Dearest
Allie. I couldn't sleep
last night because I
know that it's over
between us. I'm not
bitter anymore, because
I know that what we
had was real. And if in
some distant place in
the future we see each
other in our new lives,
I'll smile at you with
joy and remember how
we spent the summer

https://doi.org/10.36057/jilp.v3i2.404

Jurnal JILP (Jurnal Ilmiah Langue and Parole) Vol. 3 No. 2 (2020) ISSN : 2581-0804

This work is licensed under a Creative Commons Attribution-NonCommercial 4.0 International License. 
beneath the trees,

learning from each other and growing in love. The best love is the kind that awakens the soul and makes us reach for more, that plants a fire in our hearts and brings peace to our minds, and that's what you've given me. That's what I hope to give to you forever. I love you. I'll be seeing you. Noah" (82).

The devotion and Noah's commitment to allie after marriage and allie has Alzheimer's disease.

Return from the battlefield. Noah Calhoun is always haunted by the shadows of the beautiful girl he knew four years ago, and deeply loved. Although they never met again, Noah was content to live with the memories of his past ... but unexpectedly the girl returned to her city, to meet her once again.

Allie Nelson, is now engaged to another man, but she doesn't realize that her love for Noah has never faded in time. But their world is so different. Facing his marriage which was only a few weeks away, Allie was forced to question him, what exactly were his hopes and dreams for the future, and with whom he wanted to live the future. Until Allie decided with whom he could actually feel comfortable. Until the wedding of Allie and Noah. In their household relationships they also still have devotion and commitment in contradictory conditions.

The story continues back in the nursing home. Apparently the old man who read the book was Noah. Allie, his wife in the old figure at the beginning of the story suffering from Alzheimer's and forgetting Noah along with a beautiful love story in the past. Through that story, Noah tries to bring back Allie's memories. Noah is always by Allie's side even though Allie doesn't remember anything about Noah and thinks Noah is just a friend who is in the same nursing home named Duke.

"Forgive me. I have absolutely no idea what's happening to me right now. even you. Every time I hear you speak, I feel like I should know who you are, but in fact not. I don't even know who I am. "He wiped his tears and said," Help me, Duke, please help me remember who I am. Or at least, who I was. I was so confused. "(194)

Noah lied to Allie about her true name and also she lied about her own name. Noah has his own reasons for that. He must not force Allie who is suffering from Alzheimer's disease to remember which will only make Allie even sadder and feel guilty for not being able to remember everything. Noah will only read his diary over and over until Alli can remember herself. Although finally it will make Noah still sad because after remembering for some time Allie will return to normal and forget everything and make her a stranger again and of course Noah will introduce her name as Duke and read her notebook again until Allie realizes the story Noah told her is the story of the two of them.

"You are Hanna, A lover of life, a strength to those who shared in your friendship. You are a dream, a creator of happiness, an artist who has touched a thousand souls. You've led a full life and wanted for nothing, because your need are spiritual and you have only to look inside you. You are kind and loyal, and you are able to see beauty where others do not. You are a teacher of wonderful leassons, a dreamer of better things." (195). 
Noah read his diary again to Allie. Over and over until Alli remembered that what Noah had told him was himself and the Duke was Noah. After remembering that for a few moments, he was saddened by the fact that he would forget it again, forget the story told by Noah and forget who he was. With faithfulness, Noah will return to Allie's side as Duke and read her diary again. Every time Noah starts telling a story that Allie doesn't understand or Allie is confused why Noah tells her life story to herself and spends time with her.

"Why did you
spend the day with
me?" I smiled. "I'm
here because I'm
supposed to be here.
There is no specific
reason. You and I both
enjoy this. don't reject
my time, I don't feel
time is wasted. This is
what I want. I sit here
and we talk, and I
think, is there anything
better than what I'm
doing now? "(212).

When the story closed, Allie immediately remembered that the story Noah had read for days was their love story. Allie's note was written earlier and presented to Noah. On the back of the book a message was printed. It contained roughly if Allie left again, then read the contents of the notebook. Then Allie will return to Noah. Unfortunately, the memories that returned were not too long. Allie forgot her memory again and was angry because Noah hugged her and called her affectionately.

$$
\text { "I am very }
$$

scared. I'm afraid I'll forget you again. it's not fair, I don't let this happen. "His voice sounded hoarse as he ended his words, but I didn't know what to say. I knew that night would end soon, and there was nothing I could do to stop it. I really felt helpless. Finally I said to him, "I will not leave you. What we have is for ever. "(226).

Noah is always stunned how quickly that happens. When Noah was finally able to feel happy when Allie was able to remember him and remember who they really were but none of that lasted long. Even after Noah had read all the stories to Allie and had introduced himself as a Duke and spent time together it still couldn't make Allie remember all of that for a long time. Allie's eyes began to flicker rapidly, and she began to shake her head. Then, turning away toward the corner of the room, his eyes began to look at something, anxiety began to linger on his face.

\section{No! I screamed} in my heart. Not now! not right now ... not when we are so close! Not tonight! which night ... as long as not tonight $\quad .$. please! Those words raged through my mind. I can't stand it anymore! this is not fair ... this is not fair ... but, once again, it's useless. "Those people," he said later, pointing, "they are staring at me. Please stop it." (245).

A heartwarming feeling when Noah cried seeing Allie injected with sedatives. Can't bear to see the person he loves screaming hysterically. The next day, Noah had a heart attack and got emergency treatment. Sadly, Allie, who forgot her memory, just stared blankly at Noah's body being pushed into the emergency room. That night, Noah was getting better. He exits the room and looks for Allie's room. The steps are only as big as those taken by dwarves who live in straw, but even that is dangerous for him, his legs are really tired. Got caught by the nurse, Noah said, she really missed Allie. That night just want to see for a while. The sister was kind while 
stunned to see how loyal Noah was. The sister was silent for a moment, and suddenly her eyes began to water, moved to see Noah's struggle to stay by Allie's side. He would pretend to take coffee to the first floor and let Noah go to Allie's room without his knowledge.

"I tried to imagine how it feels to you, how you can survive from day to day, but it's very difficult for me. I don't know how you do it. You can sometimes beat the disease. Even though the doctors don't understand that, we nurses understand it. The answer is love, it's simple. It's really amazing." I felt like my throat was clogging, and I didn't know what to say (250).

In the room, old Noah caressed the awakened Allie. Allie's disease is not recurrent. He recognized Noah, Both again promised to be together forever. Noah also told Allie to go back to sleep, while going to sleep in the same bed.
Both hands are grasping each other. Until the morning, both of their hands were cold to the touch. That night Noah and Allie died together in their peaceful sleep. Together during life, together when death fetches.

I live a simple life now. I was indeed a silly old man who was in love, a dreamer who had no other dreams other than reading to Allie and holding his hand whenever the opportunity arose. I am a sinner with many mistakes, and a man who believes in miracles, but I am too old to change and too old to care (252).

Noah actually had a long time with heart disease. Their children and grandchildren had visited the nursing home. But Allie really doesn't remember her family. At that time, their son had asked Noah to go home. But Noah refused because Allie was his home. The mother of her children is her home. Spending the rest of his life with Allie is happiness for him.

\section{CONCLUSIONS}

In the love story between Noah and Allie who have a contradictory condition in their relationship. Noah and Allie have differences in social status and make their relationship opposed by Allie's parents, making them both separated and even for seven years never related to each other. Even so, Noah still could not forget his first love no matter how much he tried to forget. He works hard, doing everything he can forget Allie but never. Even though there were 356 letters he wrote and sent to Allie, he never got a reply, Noah still couldn't forget Allie.

The social differences between Noah and Allie made their relationship unable to continue. Allie's mother would not agree with Allie's choice to continue to have a relationship with Noah to make Allie's mother keep all the letters
Noah had sent to Allie and never give them to Allie. Allie never even knew that in fact Noah had sent hundreds of letters. An opportunity came when Noah got word that Mr Goldman had died. Noah previously worked with Mr Goldman and he got a letter from a lawyer representing Goldman. He was told that Goldman had died and Noah was making a lot of money from the business he had. Noah finally bought a house, he returned to New Bern to buy a new home for him and his father. The house is the residence that Allie's family lived in before they moved. It was by buying that house that Noah hoped that Allie would return to him.

This made local newspapers raise Noah's profile and his old home. Noah had promised to turn the old house into Allie's dream house. A 
large white house, with a large veranda for tea and tea and of course a special room for painting because Allie loves to paint. The dream house was realized by Noah, although it was renovated with a half temper. Noah had seen Allie with Lon at the restaurant. With a broken heart, Noah still believes that Allie will return to him. That house will make Allie to him. Leaving aside the difference in social status between them and the relationship that Allie's mother disapproved of, Noah would still hope that Allie would return because she could never forget Allie. Until finally Noah was able to get Allie back and marry him.

In the love story between Noah and Allie who have to separate because of differences in social status. Ms. Allie did not approve of the relationship between Allie and Noah. According to Allie Noah's mother is not a man who deserves to Allie because of differences in social status between them. Even though Allie's mother said she never hated Noah, but Allie's mother hoped that Allie was related to people who had the same social status as Allie. Allie and Noah were unrelated for seven years and for two years the letter that had been sent to Allie never reached Allie.

Allie never even knew that Noah sent 365 letters. The letters only reached Allie's mother and kept by Allie's mother without Allie's knowledge. Allie's loyalty to Noah was always there and also she never forgot Noah as Noah could never forget Allie. Allie actually wanted to write a letter and send it to Noah, but she lacked confidence. Allie thought Noah had forgotten it and Alli was afraid of that fact because even though he wanted to write a letter to Noah he hoped that Noah would send him a letter first so that Allie was not disappointed with his own feelings that he had not been able to forget about Noah. Until finally the letter written by Allie he never sent to Noah, he was afraid that Noah had forgotten it. Allie's loyalty to Noah was also seen when how happy Allie was when she got the chance to meet with Noah.

When she saw the news about Noah in a local newspaper showing Noah's profile and his old home, giving Allie the opportunity to meet Noah again even though in a few weeks he would marry his fiancée. Allie ever questioned about her life, actually what she was looking for in this life. Does She have to choose comfort that is only possible when he is with Noah or does he have to choose a man who is well established and has the same social status as him. In the end Allie prefers to be with the person who will make her comfortable and that is Noah.

The devotion and commitment of Noah to Allie after marriage and Allie who has Alzheimer's disease. During the marriage Noah and Allie are not always filled with happiness. Sometimes sadness also exists, when one of Noah's and Allie's children dies. Allie and Noah have five children and unfortunately they have to lose one of their children. Noah's loyalty to Allie did not stop there. Noah stays by Allie's side no matter what. According to Noah spending time with Allie is the most correct thing he did. When they finally got old and Allie had Alzheimer's disease, she could not get to know Noah, the children even she could not know herself.

When Allie know that her illness would get worse Allie felt very sad and felt that it was unfair to Noah. Allie will not be able to recognize Noah anymore even she will not be able to remember their memories anymore. Alli felt that it was unfair for Noah because in the end only Noah himself remembered all of that. Before her illness got worse Allie asked Noah to always read the notes he wrote in his diary. Even though someday he really can't recognize Noah even if he doesn't recognize him, he hopes that with Noah still reading his diary he will be able to remember even though it's impossible but he hopes for a miracle, at least Noah is always by his side. Noah without being asked to do that, for Naoh to spend the rest of her life with Allie is happiness. Noah will read the story of the two of them through the diary. It hurts Noah when he has to introduce himself as someone else to Allie because Allie can't recognize him anymore.

Allie thinks Noah is just a stranger in the nursing home where she lives now. in the end Noah will continue to be with Allie and read the story of the two of them until slowly Allie finally remembers who she and Noah are. Like a miracle Allie remembers the story read by Noah is about the story of the two of them even though after that memory came Allie's illness got worse and the memory disappeared quickly and made Noah returned to being a stranger to Allie. Noah's faithfulness to Allie's side was very moving for the people in the nursing home. It's like a miracle how Allie can remember even for a moment. In 
the end Noah and Allie died simultaneously in the nursing home.

For the writer, this thesis has been an effort to prove his study and at the same time to deepen his skill about literary work through writing. However, this analysis might not be perfect, so the writer wants certain inputs and critics from the readers in perfection of this writing. The writer hopes this analysis can add a new expression in literature world, especially English Department, Faculty of Literature, Universitas Ekasakti. The novel, titled The Notebook, which is carefully discussed by the author, is about devotion and commitment in contradictory conditions. Novels written by
Nicholas Sparks also have other novels that should be known to everyone. As material for novel research, it can be examined using several approaches to analyze what is contained in the novel. In addition, research on novels can also be used as a means to improve vision in the field of literature. Research on novels needs to be improved, so that the novel can be in line with the genre of prose and poetry as literary works that can be enjoyed. Not only as entertainment to read, but can also be analyzed for readers.For the reader, the writer also hopes that this writing will give the contribution to the English Department students and whoever may be interested in the subject being discussed. 


\section{Bibliography}

[1]Aan Komariah, Djam'an Satori, 2011, Metode penelitian Kualitatif. Bandung: Alfabeta.

[2]Abrams. M. H. and Harpham G. G. 2009. A Glossary of Literary Terms. London: Wadsworth.

[3]Arikunto. 2006. Prosedur penelitian suatu pendekatan praktek. Jakarta: Rineka cipta.

[4]Bernet and Burton. 1991. An Introduction to Fiction. Boston: Little Brow and Company.

[5]Bogdan and Biklen. 2009. Metode penelitian kualitatif. Bandung: Remaja Rosdakaya.

[6]Freud, Sigmund. 2002. A General Introduction to Psychoanalysis. Alih Bahasa: Ira Puspitorini Yogyakarta: Ikon Teralitera.

[7]Koswara, E. 1991. Teori-teori Kepribadiaan. Bandung: PT Eresco.
[8]Nazir. 1988. Metode penelitian. Jakarta: Ghalia Indonesia.

[9]Pradopo. Rahmat Djoko. 2001. Metodologi Penelitian Sastra. Yogyakarta: Hanindita Ghasa Widia.

[10]Puspa Arum Restuningtyas. 2016. Affection reflected in the novel notebook (1996) by Nicholas Sparks. Surakarta.

[11]Simamora Melisa Agreny. 2014. Analysis of Nicholas Sparks 'leading Character conflict' the notebook novel. Medan.

[12]Siswantoro. 2010. Metode penelitian sastra. Surakarta : pusat pelajar.

[13]Spark, Nicholas. 1996. The Notebook. New York: Hachette Book Group, Inc.

[14]Sugiyono. 2005. Metode penelitian kualitatif. Bandung: Alfabeta.

[15]Whitney. 1960. The element of research. New York: prentice-itall. 